\title{
Varicocele in the adolescent population: challenges in management
}

\author{
Varicocele no adolescente: desafios na abordagem
}

\section{Joao Paulo Cardoso, Bruno Camargo Tiseo, Marcello Cocuzza}

Cardoso JP, Tiseo BC, Cocuzza M. Varicocele in the adolescent population: challenges in management / Varicocele no adolescente: desafios na abordagem. Rev Med (São Paulo). 2018 May-June;97(3):301-7.

\begin{abstract}
Management of varicoceles in adolescents remain one of the most interesting and debatable topics. Although the crescent awareness of varicocele-induced testicular impairment has motivated several studies, some of the controversies in adult varicocele, regarding pathophysiology, treatment and fertility issues can also be transposed the adolescent population. Furthermore, adolescents represent a heterogenic group with challenges in diagnosis, clinical parameters, and limited predictors. Physical and pubertal development reflects in difficulties for standard management. The purpose of this article is to review available data from literature regarding the presentation, epidemiology and pathogenesis of varicocele in children and adolescents. We also address major limitations and challenges of clinical evaluation and provide current evidence regarding the dilemma of varicocele treatment in this particular subset of patients. Interventions options and outcomes are also discussed. The current review is based on an electronic search using Pubmed/ MEDLINE databases and references of the identified articles performed between March and May of 2018.
\end{abstract}

Keywords: Varicocele/therapy; Varicocele/physiopathology; Varicocele/epidemiology; Adolescent; Therapeutics; Review.
RESUMO: O manejo da varicocele em adolescentes continua sendo um dos tópicos mais interessantes e debatidos. Embora a crescente conscientização do comprometimento testicular induzido por varicocele tenha motivado diversos estudos, algumas das controvérsias na varicocele em adultos, em relação à fisiopatologia, tratamento e problemas de fertilidade, também podem ser transpostas para a população adolescente. Além disso, os adolescentes representam um grupo heterogêneo com desafios no diagnóstico, parâmetros clínicos e preditores de desfecho limitados. $\mathrm{O}$ desenvolvimento físico e puberal reflete-se em dificuldades para condutas padronizadas. O objetivo deste artigo é revisar os dados disponíveis da literatura sobre a apresentação, epidemiologia e patogênese da varicocele em crianças e adolescentes. Também abordamos as principais limitações e desafios da avaliação clínica e fornecemos evidências atuais sobre o dilema do tratamento com varicocele nesse subconjunto específico de pacientes. Opções de intervenção e resultados também são discutidos. A presente revisão baseia-se em uma busca eletrônica utilizando as bases de dados Pubmed / MEDLINE e referências dos artigos identificados realizadas entre março e maio de 2018.

Descritores: Varicocele/terapia; Varicocele/fisiopatologia; Varicocele/epidemiologia; Adolescente; Terapêutica; Revisão.

Departamento de Urologia, Faculdade de Medicina FMUSP, Universidade de Sao Paulo, São Paulo, SP, BR.

ORCID: Cardoso JP - https://orcid.org/0000-0003-0066-4619; Tiseo BC - https://orcid.org/0000-0003-4497-2971; Cocuzza M - https:// orcid.org/0000-0002-5465-4304. E-mail: jpgrecocardoso@gmail.com; bctiseo@gmail.com; mcocuzza@uol.com.br.

Correspondence \& Reprints: Marcello Cocuzza. Department of Urology, University of Sao Paulo (USP), Sao Paulo, Brazil. Av. Dr. Enéas de Carvalho Aguiar, 255. $7^{\circ}$ andar - Sala 710F. Cerqueira César - São Paulo, SP, Brazil. CEP: 05403-000. Email: mcocuzza@ uol.com.br. 


\section{INTRODUCTION} $\mathrm{A}_{\text {physiologically normal puberty, and ends when }}^{\text {dolescence begins with the onset of }}$ an adult identity and behavior are accepted. This period of development corresponds roughly to the period between the ages of 10 and 19 years, which is consistent with the World Health Organization's definition of adolescence ${ }^{1}$. Management of an adolescent must consider different stages of physical and pubertal development, and therefore, age must not be isolated criteria. Completely standard approaches may also not be suitable in the care of this particular subset of population.

Varicocele is defined as an abnormal dilatation, elongation and tortuosity of the pampiniform plexus, the structure in the spermatic cord responsible for venous drainage of the testis ${ }^{2}$. It affects approximately 15 $20 \%$ of the adult population globally ${ }^{3}$. Its prevalence is higher on the left side, however in almost $50 \%$ of the patients varicocele is found bilaterally. Isolate right-sided varicoceles are uncommon.

There are various theories regarding the ethiology of varicocele, not mutually exclusive. The right-angled insertion of the gonadal vein, leading to engorgement of the pampiniform plexus transmitting overload pressure, is advocated by some. Other theory postulates incompetent venous valves resulting in retrograde flux. Ultimately, another theory suggests partial obstruction of the blood flow by a compression of the left renal vein between the superior mesenteric artery and the abdominal aorta (nutcracker effect) and consequent increase of hydrostatic pressure ${ }^{4}$.

In pre-pubertal individuals, prevalence of varicocele in is low $(<1 \% \text { in boys under } 10 \text { years })^{3}$ and increases during puberty to a prevalence of $15 \%$, which is similar to that seen in adults ${ }^{5}$. Akbay et al. ${ }^{6}$ evaluated varicocele in 4092 boys aged 2-19 observing varicocele prevalence of $<1 \%$ in boys $2-10,7.8 \%$ in boys between $11-14$ and $14.1 \%$ in boys between 15-19 years old. These observations suggest that varicocele has increasing incidence during childhood and occurs during testicular development ${ }^{3}$. The mechanism is not clearly understood; one of the theories recognizes accelerated body growth and increased blood flow to the testis as probable causes of varicocele development ${ }^{6}$.

Varicocele grade and prevalence varies according to population-based or clinical studies, most likely due to referral bias. Overall, the prevalence in population-based studies ranges from 4,1 to $35,1 \%^{6-11}$, and seems to increase with patient age. Grade 1 is the most common, followed by II and III grades. On clinical studies, evaluated by urologists, varicocele tend to present during mid-to late adolescence, most commonly in grade III ${ }^{12,13}$. Increased varicocele prevalence has been observed in first-degree relatives, specially brothers, of patients with known varicoceles ${ }^{14}$.

\section{Pathogenesis}

Traditionally, varicocele has been characterized by its impact on spermatogenesis via local effects on Sertoli and germ cells. Nowadays, the potential deleterious impact in Leydig cell dysfunction is also recognized as consequence of varicocele ${ }^{15-17}$.

The pathophysiology of varicocele-induced testicular impairment has been widely studied, with no definitive answer. Suggested mechanisms are scrotal hyperthermia, hormonal disturbances, testicular hypoperfusion and hypoxia, as well as backflow of toxic metabolites ${ }^{4,18}$.

Current evidence suggests oxidative stress has a central importance in testicle function. Reactive oxygen species act in important processes in sperm physiology, such as capacitation, acrosome reaction and signalizing for fertilization ${ }^{19}$. Studies have reported increased levels of ROS in semen from infertile man with varicocele and also in men with incidental varicocele ${ }^{20-22}$. This imbalance in ROS levels would be a final path of heat stress, ischemia and production of vasodilators, such as nitric oxide ${ }^{4}$. Elevated ROS concentrations would affect several aspects, from the fluidity of sperm plasma membrane to the integrity of sperm DNA ${ }^{21}$, thus affecting male fertility.

Among adolescents, the theories are similar to adults. Elevated levels of nitric oxide have also been documented in the spermatic veins of adolescents ${ }^{23}$. Bertolla et al. ${ }^{24}$ studied adolescents with and without varicocele, and despite finding no differences in semen analysis, DNA fragmentation rates were higher in the varicocele group. Those findings suggest spermatic loss of DNA integrity as an early marker of oxidative stress.

Nonetheless, it is still not clear why some patients with varicocele are infertile and others are not ${ }^{4}$. Despite all the aforementioned theories, for the adolescent population, the question of whether to treat varicocele is still unanswered. Indications for intervention may rest in parameters such as asymmetric growth and semen analysis abnormalities, both uncertain in terms of future infertility in adolescents.

\section{Diagnosis and physical examination}

Most often, children and adolescent are brought to specialized evaluation after an incident diagnosis by their pediatrician ${ }^{25}$ or self-examination. Up to $90 \%$ of the varicocele are left-sided, with a smaller parcel being bilateral. When found isolated in the right side, it should be evaluated properly due to its potential cause. Patients with a varicocele that does not decompress in supine position also require a careful evaluation. For those patients, an ultrasound should be performed in order to identify potential retroperitoneal or renal masses that might be compressing the gonadal vein leading to elevated pressure 
in pampiniform plexus. Extension of Wilms tumor in renal vein or vena cava may also be related to a secondary varicocele ${ }^{26-29}$.

Most of the patients are asymptomatic, with approximately $5 \%$ presenting with scrotal pain ${ }^{5}$. Dull ache or "scrotal heaviness" is often referred by patients with varicocele ${ }^{30}$. Usually is greater with the patient standing, and can be eased with the patient lying down. Those who present with pain are more likely to have a higher grade varicocele ${ }^{31}$.

Varicocele is identified in physical exam, the gold standard for evaluation. Patient should be evaluated in a heated office, in both supine and orthostatic position. The scrotum is visually inspected with indirect light, and examined by palpation. In orthostatic position, the patient should be asked to perform a Valsalva maneuver Definition and grading are identical to adults, as described by Dubin and $\mathrm{Amelar}^{32}$ : grade I when varicocele is palpable with Valsalva, grade II when palpability standing only, and grade III when visible with standing. When no varicocele is found in clinical evaluation, but is detectable by ultrasonography, the denomination subclinical grade can be used - grade 0 as expanded by World Health Organization (WHO) criteria.

Testicular size and volume can be estimated in the office. Since discrepancies may be found with the use of isolated physical examination, it is recommended to use an auxiliary technique to increase accuracy. Orchidometers are available to measure testis in a clinical setting. Among several types of orchidometers, Prader's carries an accurate correlation with ultrasound measures, depending on provider experience ${ }^{33}$.

In general, ultrasound measurements are more accurate than orchidometer's measurements ${ }^{34}$. With testicular asymmetry being the principal clinical finding for indication, it is important to achieve more accuracy. Ultrasound allows the evaluation of a questionable physical examination, with more precise measurements of testicular volume and spermatic veins status ${ }^{26}$. Experience of the clinician and inter-examiner variability can influence both ultrasound and clinical measures, therefore, measurements should be analyzed over a period of time during follow-up by the same method.

\section{Seminal analysis and hormonal evaluation}

Routine use of seminal analysis in the pediatric/ adolescent population finds barriers regarding the exam and its indications. First, parameters provided by the WHO concern adult males ${ }^{35}$. Secondly, the natural history of semen analysis in adolescents is still being elucidated. Finally, beside changes in the semen profile and difficulties on the correct interpretation of the exam, there is an ethical dilemma of collecting adolescent's semen for analysis.

Studies regarding semen parameters in adolescent population found normospermia being reached beyond the $21^{\text {st }}$ month after first ejaculation, with total motile count reaching normal levels after 24 months. Before this time reference, boys are usually azoospermic or oligospermic ${ }^{36}$. Classification of adolescent samples in normospermia or oligospermia consider adult parameters, since there is no specific normal distribution for this subset of population.

In a survey by Fine et al. ${ }^{37}$ only $13.1 \%$ of responding pediatric urologists included semen analysis in their routine. Almost 50\% had some degree of discomfort, and $90 \%$ of those professionals never ordered a semen analysis for a patient with varicocele. From the patient and parents point of view, most of them were uncomfortable with obtaining a semen sample. Interestingly, lack of knowledge regarding the exam was the main barrier according to the survey. Therefore, a careful counseling would probably be able to surmount this barrier.

Nevertheless, as in adults, varicocele affects negatively semen parameters in adolescents. Previous studies by Diamond et al. ${ }^{38}$ and Mori et al. ${ }^{39}$ demonstrated lower sperm concentrations and lower progressive motility. Diamond et al. ${ }^{5}$ also reports correlation between testicular asymmetry and decrease in total motile count. Correlation between semen parameters and varicocele grade has not been established ${ }^{5}$.

As aforementioned, studies in adults have described changes in both spermatogenesis and testosterone production from varicocele. Apart from the fertility issues, the development of hypogonadism and future androgen deficiency could motivate an early intervention ${ }^{17}$.

Nonetheless, endocrine evaluation in adolescents carries practical considerations. Immaturity of the hypothalamic-pituitary-gonadal axis in the different stages of development would demand different standards for evaluation ${ }^{40}$. Fideleff et al. ${ }^{41}$ performed a prospective study with 93 adolescents and found no difference in hormonal parameters of FSH, LH, Testosterone and GnRH from varicocele individuals and controls, even after correction of Tanner stage. Although recent studies in adults have so far demonstrated improvement in hormonal parameters after varicocelectomy ${ }^{42}$, there is no available data to correlate this studies for the adolescent population.

\section{Treatment: indications and options}

Awareness of the potential damage associated with long standing varicoceles has motivated urologists to become more conscientious in their pursuit of adolescent varicocele treatment. There is an assumption that varicocelectomy would cease the effects of varicocele, while observation would result in future infertility ${ }^{25}$ or testicular dysfunction.

Routine surgery is inappropriate for all adolescents, since it is not cost effective and fertility will not necessarily be affected by varicocele, as exposed before. Non-selective surgical intervention would submit a large population 
of boys to unnecessary surgery. On the other hand, it is unacceptable to allow a potentially reversible cause to manifest as infertility or other testicular dysfunction in adult age.

Indications for treatment of varicoceles in pediatric/ adolescents vary among urologists. A survey conducted by Pastuszak et al. ${ }^{43}$ among pediatric urologists revealed that $96 \%$ of surgical referrals were due to diminished ipsilateral testicular size, $79 \%$ for testicular pain and $39 \%$ for semen parameters alterations.

Testicular asymmetry is the principal clinical finding for indication, albeit a controversial criteria. Available studies are heterogeneous in methodology, using clinical and ultrasonographic measures. What consists an asymmetry is one of the main points of debate, with studies describing absolute size differentials of 2 or $3 \mathrm{~mL}^{44}$, and/or relative size differentials from 10 to $15 \%{ }^{45}$. Natural history of the asymmetry is also controversial. Previous studies reported resolution of size asymmetry in up to $71 \%$ of patients in a long follow-up ${ }^{46}$ while other reports discrepant findings with $43 \%$ progression of asymmetry.

Regarding to semen analysis, Chu et al. ${ }^{47}$, using semen analysis to follow-up, described adolescents with normal sized testicles and varicocele, with improvement in total motile counts even without surgery. On the other way, Locke et al. ${ }^{48}$ performed a systematic review and metaanalysis of randomized controlled trials in adolescents. Overall, combining the similar studies, there is a low to moderate level of evidence that varicocele treatment is associated with improvement in testicular volume and semen concentration, with no difference in motility or morphology ${ }^{49-51}$.

Pain is probably the least controversial and most acceptable indication for treatment of varicoceles in adolescents. Data from previous studies, although performed in adults, have demonstrated an overall resolution of $61-100 \%$, specially for sharp pain. Other conservative treatments have not been as effective ${ }^{5}$.

In summary, despite all controversies involving indication, parameters and moment for intervention, the clinical guidelines and best practice statements remain with common indications being testicular size discrepancy, semen analysis, when available, and pain ${ }^{25}$.

Varicocelectomy method is another field of debate in the treatment of adolescent varicocele. Both surgical and non-surgical treatments may be considered. Percutaneous sclerotherapy or embolization are the nonsurgical methods. Surgical options include Palomo (high retroperitoneal), Ivanissevich (inguinal) or microscopic inguinal or subinguinal.

Locke et $a .^{48}$, in a recent systematic review and meta-analysis, describe recurrence rates for open varicocelectomy between 0 and $31 \%$, and for laparoscopic interventions rates between 0 and $8 \%$. Lymphatic sparing techniques studies reported rates from 0 to $2 \%$. Hydrocele occurrence rates stand between 0 and $17 \%$ for open techniques and 0 to $13 \%$ in laparoscopic techniques. Approaches with lymphatic sparing techniques describe hydrocele occurrence in $0-2 \%$ of patients ${ }^{48}$.

Interestingly, the choice of a laparoscopic Palomo technique is more common between pediatric surgeons, while the microscopic open inguinal or subinguinal approaches are preferred by urologists. This is probably due to inexperience or lack of familiarity with the microsurgical technique among pediatric surgeons. Another possibility is the fear of rare testicular atrophy after spermatic vein ligation. Nevertheless, several groups have safely performed microsurgical varicocelectomy in children and adolescents with no cases of testicular atrophy ${ }^{52}$.

Therefore, microsurgical varicocelectomy performed through an inguinal or subinguinal incision is recognized as the gold-standard approach to varicocelectomy, with high success rates and minimal complications ${ }^{53}$. Operating microscope allows an minimally invasive access and preservation of the testicular artery and lymphatics vessels, resulting in lower recurrence rates as well as lower rates of hydrocele after the procedure ${ }^{54}$. Technique for microsurgical approach is similar to that performed in adults, and previous studies also describe safety and effectiveness of the method in adolescent population ${ }^{55,56}$.

The European Society of Pediatric Urology (ESPU) recommends optical magnification when open surgical access is used. EAU (Europeans Association of Urology) also highlights the advantages of microscopic approach in their guideline as described in the next section.

\section{Guidelines and best practice statements}

Roque et al. ${ }^{29}$ performed a systematic review of clinical practice guidelines and best practice statements with recommendations from AUA (American Urological Association), ASRM (American Society for Reproductive Medicine), EAU (European Association of Urology) and ESPU (European Society of Paediatric Urology). Most of the recommendations derived from nonrandomized clinical trials, retrospective studies and expert opinion. Differences in methods, data collection and analysis make clinical practice guidelines and best practices statements hard to be summarize in single statements. Nonetheless, when combined with physician judgement, guidelines may help to enhance quality of health care.

Overall, diagnosis is achieved by physical examination as a standard for all guidelines. AUA and ASRN recommends ultrasound only for inconclusive examinations, while EAU recommends color duplex analysis for confirmation in all patients. ESPU is specific in recommending US for confirmations of orchidometer measurements and states a $20 \%$ or $2 \mathrm{~mL}$ difference between testis as hypoplasia. In terms of treatment indications, AUA recommends treatment for reduced ipsilateral 
testicular size, and follow-up with testicular size and/or seminal analysis for symmetric testis. ASRM includes bilateral varicocele in their recommendations, apart from the AUA statements. EAU recommends treatment for testicular asymmetry in follow-up, with a level of evidence 3 observation of possible overtreatment. ESPU has de widest recommendation for treatments, including: testicular hypoplasia, bilateral varicocele, pathological sperm quality in adolescents, symptomatic varicocele and additional testicular condition affecting fertility. Finally, for treatment modalities, AUA recommends treatment according to physician expertise. ASRM assumes different possibilities of treatment, both surgical and percutaneous, but comments on lower rates of complications and recurrence with microsurgical approaches. EAU also comments in microsurgical advantages. ESPU recommends use of optical magnification and lymphatic-sparing procedure. Recommendations are summarized in Table 1.

Table 1: Summary of clinical guidelines and best practice statement

\begin{tabular}{|c|c|c|c|}
\hline & Diagnosis & Indication & Treatment options \\
\hline AUA & $\begin{array}{l}\text { Physical examination; confirm } \\
\text { suspected varicocele with } \\
\text { ultrasound }\end{array}$ & $\begin{array}{l}\text { Offer varicocele ligation for objective } \\
\text { testicular asymmetry. Follow up } \\
\text { for patients with normal ipsilateral } \\
\text { testicular size }\end{array}$ & $\begin{array}{l}\text { Choice of treatment based on } \\
\text { physician's expertise }\end{array}$ \\
\hline ASRM & $\begin{array}{l}\text { Physical examination; ultrasound } \\
\text { for inconclusive clinical approach }\end{array}$ & $\begin{array}{l}\text { Offer varicocele ligation for patients } \\
\text { with unilateral or bilateral varicocele } \\
\text { with ipsilateral reduced testicular size }\end{array}$ & $\begin{array}{l}\text { Surgical or percutaneous approaches. } \\
\text { Consider lower recurrence rates and } \\
\text { complication rates in microsurgical } \\
\text { managements }\end{array}$ \\
\hline EAU & $\begin{array}{l}\text { Physical examination should be } \\
\text { confirmed by color duplex }\end{array}$ & $\begin{array}{l}\text { Recommend treatment if testicular } \\
\text { asymmetry in serial follow up (grade } \\
\text { B). Risk of overtreatment (level of } \\
\text { evidence } 3 \text { ). }\end{array}$ & $\begin{array}{l}\text { Microsurgical approach as the most } \\
\text { effective and least morbid method. }\end{array}$ \\
\hline ESPU & $\begin{array}{l}\text { Clinical examination, upright } \\
\text { position. Confirm testicle } \\
\text { asymmetry by ultrasound or } \\
\text { orchidometer. Testis smaller } \\
\text { by } 2 \mathrm{ml} \text { or } 20 \% \text { in comparison } \\
\text { considered asymmetric. }\end{array}$ & $\begin{array}{l}\text { Recommended treatment: small testis } \\
\text { associated with varicocele, bilateral } \\
\text { palpable varicocele, abnormalities in } \\
\text { sperm analysis (older adolescents), } \\
\text { symptomatic varicocele, other } \\
\text { conditions affecting fertility. }\end{array}$ & $\begin{array}{l}\text { Use of optical magnification for } \\
\text { surgical ligation (level of evidence } 3 \\
\text { grade B). Testicular hypotrophy and } \\
\text { hydrocele prevented by lymphatic- } \\
\text { sparing techniques. }\end{array}$ \\
\hline
\end{tabular}

Adapted from Roque et al. ${ }^{29}$

\section{CONCLUSION}

Considerable debate remains regarding evaluation, management, and treatment for varicocele in adolescents. Adolescents are a heterogeneous group with rapidly changing hormonal levels, different stages of physical and pubertal development and therefore represent a challenge to standard approaches.

Ideally, we should be able to predict fertility outcomes, and identify a subgroup of adolescents more likely to benefit from treatment. The available literature does not provide adequate evidence to identify this subgroup, nor long-term outcomes. Therefore, despite all controversies, common indications remain being testicular size discrepancy, semen analysis and pain. Testicular asymmetry is the principal clinical finding for indication, and pain is the least controversial. Long term follow-up and randomized clinical trials would add important evidence to this debatable and interesting subject.

Conflict of interest: none.

Support/funding: none.

\section{REFERENCES}

1. Age limits and adolescents. Paediatr Child Health. 2003;8(9):577-8. Available from: https://www.ncbi.nlm.nih. gov/pmc/articles/PMC2794325/.

2. Paduch DA, Skoog SJ. Diagnosis, evaluation and treatment of adolescent varicocele. ScientificWorld J. 2004;4(Suppl 1):263-78. doi: 10.1100/tsw.2004.76.

3. Alsaikhan B, Alrabeeah K, Delouya G, Zini A. Epidemiology of varicocele. Asian J Androl. 2016;18(2):179-81. doi: 10.4103/1008-682X.172640.

4. Agarwal A, Hamada A, Esteves SC. Insight into oxidative stress in varicocele-associated male infertility: part 1. Nat Rev Urol. 2012;9(12):678-90. doi: 10.1038/nrurol.2012.197.

5. Sack BS, Schäfer M, Kurtz MP. The dilemma of adolescent varicoceles: Do they really have to be repaired? Curr Urol Rep. 2017;18(5):38. doi: 10.1007/s11934-017-0686-7.

6. Akbay E, Cayan S, Doruk E, Duce MN, Bozlu M. The prevalence of varicocele and varicocele-related testicular atrophy in Turkish children and adolescents. BJU Int. 2000;86(4):490-3. https://doi.org/10.1046/j.1464- 
Cardoso JP, et al. Varicocele in the adolescent population: challenges in management.

410X.2000.00735.x.

7. Kumanov P, Robeva RN, Tomova A. Adolescent varicocele: who is at risk? Pediatrics. 2008;121(1):e53-7. doi: 10.1542/ peds.2007-0340.

8. Niedzielski J, Paduch D, Raczynski P. Assessment of adolescent varicocele. Pediatr Surg Int. 1997;12(5-6):410413.

9. Stavropoulos NE, Mihailidis I, Hastazeris K, Moisidou R, Louka G, Filiadis I, Zouma E, Danella M, Kalomiris P. Varicocele in schoolboys. Arch Androl. 2002;48(3):187-92. DOI: $10.1080 / 01485010252869270$.

10. Zampieri N, Cervellione RM. Varicocele in adolescents: a 6-year longitudinal and followup observational study. J Urol. 2008;180(4 Suppl):1653-6; discussion 1656. doi: 10.1016/j. juro.2008.03.114.

11. Pajovic B, Radojevic N. Prospective follow up of fertility after adolescent laparoscopic varicocelectomy. Eur Rev Med Pharmacol Sci. 2013;17(8):1060-3. Available from: https://www.europeanreview.org/wp/wp-content/ uploads/1060-1063.pdf.

12. Çayan S, Şahin S, Akbay E. Paternity rates and time to conception in adolescents with varicocele undergoing microsurgical varicocele repair vs observation only: a single institution experience with 408 patients. J Urol. 2017;198(1):195-201. doi: 10.1016/j.juro.2017.01.066.

13. Kozakowski KA, Gjertson CK, Decastro GJ, Poon S, Gasalberti A, Glassberg KI. Peak retrograde flow: a novel predictor of persistent, progressive and new onset asymmetry in adolescent varicocele. J Urol. 2009;181(6):2717-22; discussion 2723. doi: 10.1016/j.juro.2009.02.038.

14. Raman JD, Walmsley K, Goldstein M. Inheritance of varicoceles. Urology. 2005;65(6):1186-9. doi: doi: 10.1016/j. urology.2004.12.057.

15. Schlegel PN, Goldstein M. Alternate indications for varicocele repair: non-obstructive azoospermia, pain, androgen deficiency and progressive testicular dysfunction. Fertil Steril. 2011;96(6):1288-93. doi: 10.1016/j.fertnstert.2011.10.033.

16. Weiss DB, Rodriguez-Rigau LJ, Smith KD, Steinberger E. Leydig cell function in oligospermic men with varicocele. J Urol. 1978;120(4):427-30. https://doi.org/10.1016/S00225347(17)57214-6.

17. Tanrikut C, Goldstein M, Rosoff JS, Lee RK, Nelson CJ, Mulhall JP. Varicocele as a risk factor for androgen deficiency and effect of repair. BJU Int. 2011;108(9):1480-4. doi: 10.1111/j.1464-410X.2010.10030.x.

18. Sheehan MM, Ramasamy R, Lamb DJ. Molecular mechanisms involved in varicocele-associated infertility. J Assist Reprod Genet. 2014;31(5):521-6. doi: 10.1007/s10815-014-0200-9.

19. Saleh RA, Agarwal A. Oxidative stress and male infertility: from research bench to clinical practice. J Androl. 2002;23(6):73752. https://doi.org/10.1002/j.1939-4640.2002.tb02324.x.

20. Sharma RK, Agarwal A. Role of reactive oxygen species in male infertility. Urology. 1996;48(6):835-50. https://doi.
org/10.1016/S0090-4295(96)00313-5.

21. Saleh RA, Agarwal A, Sharma RK, Said TM, Sikka SC, Thomas AJ. Evaluation of nuclear DNA damage in spermatozoa from infertile men with varicocele. Fertil Steril. 2003;80(6):1431-6. https://doi.org/10.1016/S00150282(03)02211-8.

22. Hendin BN, Kolettis PN, Sharma RK, Thomas AJ, Agarwal A. Varicocele is associated with elevated spermatozoal reactive oxygen species production and diminished seminal plasma antioxidant capacity. J Urol. 1999;161(6):1831-4. https://doi. org/10.1016/S0022-5347(05)68818-0.

23. Romeo C, Ientile R, Impellizzeri P, et al. Preliminary report on nitric oxide-mediated oxidative damage in adolescent varicocele. Hum Reprod. 2003;18(1):26-9. https://doi. org/10.1093/humrep/deg004.

24. Bertolla RP, Cedenho AP, Hassun Filho PA, Lima SB, Ortiz V, Srougi M. Sperm nuclear DNA fragmentation in adolescents with varicocele. Fertil Steril. 2006;85(3):625-8. doi: 10.1016/j.fertnstert.2005.08.032.

25. Jacobson DL, Johnson EK. Varicoceles in the pediatric and adolescent population: threat to future fertility? Fertil Steril. 2017;108(3):370-7. doi: 10.1016/j.fertnstert.2017.07.014.

26. Chung JM, Lee SD. Current issues in adolescent varicocele: pediatric urological perspectives. World J Mens Health. 2018;36(2):123-31. doi: 10.5534/wjmh.170053.

27. Masson P, Brannigan RE. The varicocele. Urol Clin North Am. 2014;41(1):129-44. doi: 10.1016/j.ucl.2013.08.001.

28. Vasavada S, Ross J, Nasrallah P, Kay R. Prepubertal varicoceles. Urology. 1997;50(5):774-7. doi: 10.1016/S00904295(97)00332-4.

29. Roque M, Esteves SC. A systematic review of clinical practice guidelines and best practice statements for the diagnosis and management of varicocele in children and adolescents. Asian J Androl. 2016;18(2):262-8. doi: 10.4103/1008-682X.169559.

30. Yaman O, Ozdiler E, Anafarta K, Göğüş O. Effect of microsurgical subinguinal varicocele ligation to treat pain. Urology. 2000;55(1):107-8. https://doi.org/10.1016/S00904295(99)00374-X.

31. Han DY, Yang QY, Chen X, et al. Who will benefit from surgical repair for painful varicocele: a meta-analysis. Int Urol Nephrol. 2016;48(7):1071-8. doi: 10.1007/s11255-0161246-7.

32. Dubin L, Amelar RD. Varicocele size and results of varicocelectomy in selected subfertile men with varicocele. Fertil Steril. 1970;21(8):606-9. https://doi.org/10.1016/ S0015-0282(16)37684-1.

33. Schiff JD, Li PS, Goldstein M. Correlation of ultrasonographic and orchidometer measurements of testis volume in adults. BJU Int. 2004;93(7):1015-7. doi: 10.1111/j.1464410X.2003.04772.x.

34. al Salim A, Murchison PJ, Rana A, Elton RA, Hargreave TB. Evaluation of testicular volume by three orchidometers compared with ultrasonographic measurements. Br J Urol. 
Cardoso JP, et al. Varicocele in the adolescent population: challenges in management.

1995;76(5):632-5. https://doi.org/10.1111/j.1464-410X.1995. tb07792.x.

35. Cooper TG, Noonan E, von Eckardstein S, et al. World Health Organization reference values for human semen characteristics. Hum Reprod Update. 2010;16(3):231-45. doi: 10.1093/humupd/dmp048.

36. Janczewski Z, Bablok L. Semen characteristics in pubertal boys. III. Semen quality and somatosexual development. Arch Androl. 1985;15(2-3):213-8.

37. Fine RG, Gitlin J, Reda EF, Palmer LS. Barriers to use of semen analysis in the adolescent with a varicocele: Survey of patient, parental, and practitioner attitudes. J Pediatr Urol. 2016;12(1):41.e41-46. doi: 10.1016/j.jpurol.2015.06.015.

38. Diamond DA, Zurakowski D, Bauer SB, et al. Relationship of varicocele grade and testicular hypotrophy to semen parameters in adolescents. J Urol. 2007;178(4 Pt 2):1584-8. doi: 10.1016/j.juro.2007.03.169.

39. Mori MM, Bertolla RP, Fraietta R, Ortiz V, Cedenho AP. Does varicocele grade determine extent of alteration to spermatogenesis in adolescents? Fertil Steril. 2008;90(5):176973. doi: 10.1016/j.fertnstert.2007.09.052.

40. de Los Reyes T, Locke J, Afshar K. Varicoceles in the pediatric population: Diagnosis, treatment, and outcomes. Can Urol Assoc J. 2017;11(1-2Supp11):S34-S39. doi: 10.5489/ cuaj. 4340 .

41. Fideleff HL, Boquete HR, Suárez MG, et al. Controversies in the evolution of paediatric-adolescent varicocele: clinical, biochemical and histological studies. Eur J Endocrinol. 2000;143(6):775-81. doi: 10.1530/eje.0.1430775.

42. Tanrikut C, Goldstein M. Varicocele repair for treatment of androgen deficiency. Curr Opin Urol. 2010;20(6):500-2. doi: 10.1097/MOU.0b013e32833flb5e.

43. Pastuszak AW, Kumar V, Shah A, Roth DR. Diagnostic and management approaches to pediatric and adolescent varicocele: a survey of pediatric urologists. Urology. 2014;84(2):450-5. doi: 10.1016/j.urology.2014.04.022.

44. Jarow JP, Coburn M, Sigman M. Incidence of varicoceles in men with primary and secondary infertility. Urology. 1996;47(1):73-6. https://doi.org/10.1016/S00904295(99)80385-9.

45. Sayfan J, Siplovich L, Koltun L, Benyamin N. Varicocele treatment in pubertal boys prevents testicular growth arrest. J Urol. 1997;157(4):1456-7. https://doi.org/10.1016/S00225347(01)65021-3.

46. Kolon TF, Clement MR, Cartwright L, et al. Transient asynchronous testicular growth in adolescent males with a varicocele. J Urol. 2008;180(3):1111-4; discussion 1114-5. doi: 10.1016/j.juro.2008.05.061.

47. Chu DI, Zderic SA, Shukla AR, et al. The natural history of semen parameters in untreated asymptomatic adolescent varicocele patients: A retrospective cohort study. J Pediatr Urol. 2017;13(1):77.e71-77.e75. doi: 10.1016/j. jpurol.2016.09.008

48. Locke JA, Noparast M, Afshar K. Treatment of varicocele in children and adolescents: A systematic review and metaanalysis of randomized controlled trials. J Pediatr Urol. 2017;13(5):437-45. doi: 10.1016/j.jpurol.2017.07.008

49. Laven JS, Haans LC, Mali WP, te Velde ER, Wensing CJ, Eimers JM. Effects of varicocele treatment in adolescents: a randomized study. Fertil Steril. 1992;58(4):756-62. https:// doi.org/10.1016/S0015-0282(16)55324-2.

50. Paduch DA, Niedzielski J. Repair versus observation in adolescent varicocele: a prospective study. J Urol. 1997;158(3 Pt 2):1128-32. https://doi.org/10.1016/S00225347(01)64403-3.

51. Mohseni MJ, Nazari H, Amini E, et al. Shunt-type and stop-type varicocele in adolescents: prognostic value of these two different hemodynamic patterns. Fertil Steril. 2011;96(5):1091-6. doi: 10.1016/j.fertnstert.2011.08.024.

52. Harel M, Herbst KW, Nelson E. Practice patterns in the surgical approach for adolescent varicocelectomy. Springerplus. 2015;4:772. doi: 10.1186/s40064-015-1573-7.

53. Mehta A, Goldstein M. Microsurgical varicocelectomy: a review. Asian J Androl. 2013;15(1):56-60. doi: 10.1038/ aja.2012.98.

54. Goldstein M, Gilbert BR, Dicker AP, Dwosh J, Gnecco C. Microsurgical inguinal varicocelectomy with delivery of the testis: an artery and lymphatic sparing technique. J Urol. 1992;148(6):1808-11. https://doi.org/10.1016/S00225347(17)37035-0.

55. Silveri M, Adorisio O, Pane A, Colajacomo M, De Gennaro M. Subinguinal microsurgical ligation--its effectiveness in pediatric and adolescent varicocele. Scand J Urol Nephrol. 2003;37(1):53-4. doi: 10.1080/00365590310008703.

56. Lemack GE, Uzzo RG, Schlegel PN, Goldstein M. Microsurgical repair of the adolescent varicocele. J Urol. 1998;160(1):179-81. https://doi.org/10.1016/S00225347(01)63086-6.

Submitted for publication: Apr 29, 2018

Accepted in: May 22, 2018 